\title{
STUDI ANALISIS DAN PERANCANGAN SISTEM E-INNOVATION DENGAN MENGGUNAKAN VOTING DAN ANALYTICAL HIERARCHY PROCESS UNTUK MENAMPUNG IDE INOVASI DI DINAS PERDAGANGAN DAN PERINDUSTRIAN KOTA SURABAYA
}

\author{
Adhika Dwi Pramudita, Rinabi Tanamal \\ Universitas Ciputra
}

r.tanamal@ciputra.ac.id

\begin{abstract}
The problem is how to design and make E-Innovation technology prototype using Analytical Hierarchy Process. The purpose of this project is designing and making the $E$ Innovation prototype which gives solution to increase quantity and quality of Innovation ideas at Dinas Perdagangan dan Perindustrian Kota Surabaya. The Methods used to design and making the E-Innovation prototype are interview, observation, and experiment. The goal is to increase quantity and quality of Innovation ideas at Dinas Perdagangan dan Perindustrian Kota Surabaya.
\end{abstract}

Keywords: Dinas Perdagangan dan Perindustrian Kota Surabaya, Innovation, E-Innovation, Analytical Hierarchy Process.

\section{Latar Belakang}

Dinas Perdagangan dan Perindustrian Kota Surabaya merupakan salah satu lembaga pelayanan publik terbaik yang dipunyai oleh Kota Surabaya berdasarkan penilaian dari lembaga independen yang ditunjuk oleh Pemerintah Kota Surabaya. Dinas ini telah berkalikali memenangkan penghargaan sebagai lembaga dengan pelayanan terbaik terhadap masyarakat Kota Surabaya. Mereka terkenal dengan inovasi layanan yang terus menerus diperbaharui untuk pelayanan yang lebih baik. Inovasi adalah hal dasar yang diandalkan oleh Dinas Perdagangan dan Perindustrian Kota Surabaya.

Pada pelaksanaannya, masih banyak hambatan yang menghalangi Dinas Perdagangan dan Perindustrian Kota Surabaya melakukan inovasi. Pertama, berdasarkan hasil observasi pada tanggal 24 - 28 Oktober 2011 terlihat bahwa pegawai negeri sipil di Dinas Perdagangan dan Perindustrian Kota Surabaya sendiri cenderung hanya melakukan pekerjaan standard yang telah ditetapkan. Hal ini mengakibatkan kurang munculnya inovasi untuk menghasilkan layanan yang lebih baik. Sistem saat ini tidak memberikan kredit lebih bagi mereka yang terus-menerus menciptakan inovasi layanan yang bagus. Dampaknya, jumlah inovasi yang muncul sangat sedikit untuk diolah menjadi layanan baru yang bagus.

Kedua, hambatan struktural yang ada sangat mengekang pegawai yang mempunyai potensi lebih. Pegawai yang mempunyai ide inovasi, harus melapor kepada Kepala Seksi atau Kepala Bidang. Apabila Kepala Seksi atau Kepala Bidang tidak menyampaikan ide inovasi tersebut terhadap Kepala Dinas dalam rapat, maka ide inovasi tersebut tidak akan pernah terwujud. Sering juga Kepala Seksi atau Kepala Bidang mengklaim ide pegawai tersebut sebagai ide mereka, sehingga merekalah yang mendapatkan kredit, bukan pegawai yang bersangkutan.

Oleh karena itu, diperlukan sebuah sistem baru yang memungkinkan karyawan yang awalnya malas menjadi termotivasi untuk mengeluarkan ide inovasi sekaligus menemukan karyawan berpangkat rendah namun berpotensi tinggi yang selama ini tertutupi oleh Kepala 
Seksi atau Kepala Bidang mereka. Ide E-Innovation akan menyelesaikan masalah ini. Sebuah internal web-based system yang dapat diakses seluruh pegawai Disperdagin dengan fitur-fitur khusus yang memungkinkan sebuah ide inovasi dapat diolah secara bersama-sama serta pemilik ide mendapatkan kredit khusus berupa penambahan poin.

Sebuah ide inovasi akan dapat divoting oleh karyawan lain. Bobot nilai setiap voting akan berbeda dan ditentukan dengan metode Analytical Hierarchy Process. Apabila sudah mendapatkan jumlah poin tertentu, maka pegawai tersebut dapat menukarkannya dengan point E-Performance, sebuah software yang telah tersedia di pemerintahan Kota Surabaya untuk dapat menambah penghasilan mereka.

Dengan dapat menukarkan point E-Innovation dengan point E-Performance, diharapkan dapat menyelesaikan masalah motivasi pegawai negeri dalam memberikan ide inovasi baru. Semakin banyak dan berkualitas ide inovasi yang mereka keluarkan, semakin besar kemungkinan mereka mendapatkan penghasilan tambahan. Pada akhir setiap cycle, pegawai negeri berhak memasukkan kontribusi mereka dari E-Innovation ke E-Performance secara manual.

Pada sistem Analytical Hierarchy Process, diharapkan proses pemilihan ide inovasi dapat berjalan secara adil. Fitur ini akan membuat karyawan bertalenta tinggi yang sebelumnya tertutupi oleh atasan langsungnya, kini dapat menunjukkan kemampuan mereka kepada semua orang di organisasi. Apabila mereka terus-menerus memberikan ide inovasi melalui E-Innovation, maka bakat mereka pasti akan diketahui oleh Kepala Dinas dan bisa mendapatkan penghasilan tambahan atau malah kenaikan pangkat.

\section{Metode}

Metodologi penelitian yang digunakan dalam pembuatan tugas akhir ini adalah :

1. Studi literatur mengenai metode Analytical Hierarchy Process, penilaian sistem kinerja karyawan, dan bagaimana cara meningkatkan inovasi dalam sebuah perusahaan.

2. Pembuatan pertanyaan wawancara untuk mendapatkan data-data, informasi yang diperlukan, dan fitur-fitur yang diminta.

3. Perhitungan metode Analytic Hierarchy Process berdasarkan data-data yang didapatkan serta menentukan bobot nilai voting tiap pangkat/jabatan.

4. Proses perancangan dan pembuatan software requirements specification untuk teknologi E-Innovation.

5. Melakukan testing menggunakan prototype low-fidelity.

6. Membuat kesimpulan dari hasil testing.

7. Penulisan laporan.

\section{Hasil dan Pembahasan}

\section{Model Innovation Tournament}

Apabila organisasi mengecek dan menganalisa ide inovasi yang diberikan oleh anggota satu per satu, tentunya akan memakan waktu cukup lama. Tentu sistem ini tidak akan cocok diterapkan dalam organisasi besar dengan ratusan atau bahkan ribuan karyawan di dalamnya yang ingin memberikan sumbangan terhadap kemajuan perusahaan. Untuk mempercepat proses seleksi inovasi, digunakan Innovation tournament.

Innovation tournament biasanya digunakan untuk menyaring ribuan ide inovasi menjadi beberapa ide yang sangat kuat. Di dalam Innovation tournament, terdapat beberapa level filter yang akan membantu organisasi mencari ide inovasi yang terbaik. Organisasi 
hanya perlu untuk mencari jenis filter yang tepat di masing-masing levelnya. Berikut adalah contoh model Innovation tournament yang sederhana.

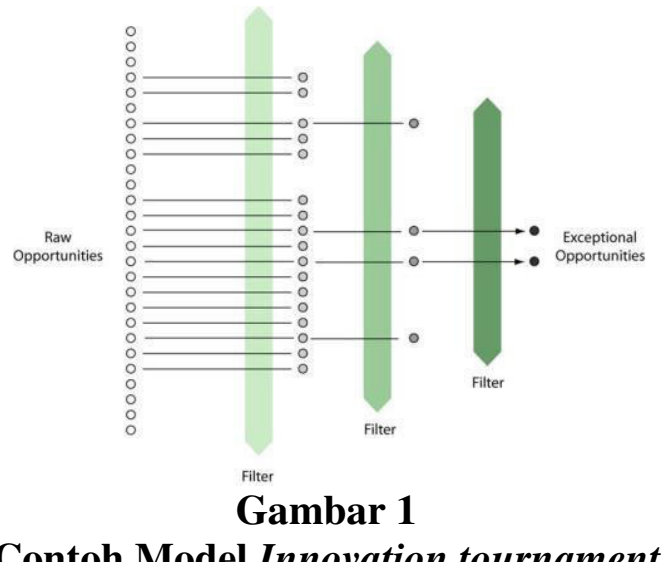

Sumber: Terwiesch and Ulrich, 2009

Aplikasi E-Innovation akan menggunakan Innovation tournament sebagai kerangka dasar pembuatannya. E-Innovation akan mampu untuk menyediakan dua buah filter untuk Dinas Perdagangan dan Perindustrian Kota Surabaya. Filter pertama akan berupa power vote dan filter kedua berupa Analytical Hierarchy Process menggunakan dimensi bisnis Fontana. Inovasi-inovasi yang telah lolos dari dua filter ini kemudian akan menjadi masukan untuk rapat tentang kemungkinan inovasi yang dapat diterapkan di Dinas Perdagangan dan Perindustrian Kota Surabaya.

\section{Power Vote}

Sistem power vote adalah filter pertama untuk mewujudkan teori Innovation tournament dalam aplikasi E-Innovation untuk Dinas Perdagangan dan Perindustrian Kota Surabaya. Seperti namanya, power vote tidak sama dengan sistem vote biasa. Apabila sistem vote dalam forum yang standard, semua vote bernilai 1, maka dalam power vote, nilai vote bisa berbeda-beda tergantung dengan siapa yang memberikan vote. Sistem vote biasa sangat tidak cocok dengan hasil wawancara yang menunjukkan struktur organisasi yang cukup dalam dari Dinas Perdagangan dan Perindustrian Kota Surabaya.

Pertama, ada banyak sekali level yang memisahkan antara Kepala Dinas dengan karyawan biasa. Pola piramida juga ditemukan dalam struktur organisasi ini, menyebabkan semakin tinggi jabatan, semakin sedikit orang yang mendudukinya. Jabatan yang lebih tinggi menunjukkan pengalaman dan pengetahuan seseorang di bagiannya. Posisi karyawan operasional mempunyai jumlah karyawan yang sangat banyak, namun tentunya dengan pengalaman dan pengetahuan yang jauh dibawah atasan mereka.

Masalah kedua datang dari struktur organisasi yang memisahkan masing-masing department juga menyebabkan karyawan menjadi sangat spesialis, hanya mengerjakan apa yang di departmentnya kerjakan. Karyawan tidak boleh mengerjakan hal lain yang selain tanggung jawabnya yang telah ditulis di undang-undang dan peraturan pemerintah yang telah terbit. Hal ini menyebabkan karyawan hanya mempunyai pengetahuan tentang departmennya dan sedikit atau bahkan tidak sama sekali pengetahuan tentang department lain.

Berikut adalah daftar nilai vote yang akan dipakai untuk dasar power vote dalam $E$ Innovation yang sudah disetujui oleh Dinas Perdagangan dan Perindustrian Kota Surabaya: 
Tabel 1

Nilai power vote yang sudah ditentukan

\begin{tabular}{|c|c|}
\hline Jabatan & Value Dalam Bagian Masing-Masing \\
\hline Pengadministrasian Umum 3 & 0,5 \\
\hline Pengadministrasian Umum 2 & 0,5 \\
\hline Jabatan & Value Dalam Bagian Masing-Masing \\
\hline Pengadministrasian Umum 1 & 1 \\
\hline Pengadministrasian Tertentu 3 & 1 \\
\hline Pengadministrasian Tertentu 2 & 1 \\
\hline Pengadministrasian Tertentu 1 & 1,5 \\
\hline Petugas Operasional 3 & 1,5 \\
\hline Petugas Operasional 2 & 1,5 \\
\hline Petugas Operasional 1 & 2 \\
\hline Penyelia Teknis 3 & 2 \\
\hline Penyelia Teknis 2 & 2 \\
\hline Penyelia Teknis 1 & 2,5 \\
\hline Perencana Teknis 3 & 2,5 \\
\hline Perencana Teknis 2 & 3 \\
\hline Perencana Teknis 1 & 3 \\
\hline Verifikator & 3 \\
\hline Analis 3 & 4 \\
\hline Analis 2 & 5 \\
\hline Analis 1 & 6 \\
\hline Sub Bagian Tata Usaha & 7 \\
\hline UPTD Pasar Turi & 8 \\
\hline Seksi Perdagangan Dalam Negeri & 7 \\
\hline Seksi Perdagangan Luar Negeri & 7 \\
\hline Kepala Bidang Perdagangan & 8 \\
\hline $\begin{array}{l}\text { Seksi Logam, Mesin, Elektronika } \\
\& \text { Aneka }\end{array}$ & 7 \\
\hline $\begin{array}{l}\text { Seksi Industri Kimia, Agro \& } \\
\text { Hasil Hutan }\end{array}$ & 7 \\
\hline Jabatan & Value Dalam Bagian Masing-Masing \\
\hline Kepala Bidang Industri & 8 \\
\hline Seksi Promosi & 7 \\
\hline Seksi Pendaftaran Perusahaan & 7 \\
\hline $\begin{array}{l}\text { Kepala Bidang Promosi \& } \\
\text { Pendaftaran Perusahaan }\end{array}$ & 8 \\
\hline $\begin{array}{lll}\text { Sub } & \text { Bagian } & \text { Umum }\end{array}$ & 7 \\
\hline Sub Bagian Keuangan & 7 \\
\hline Kepala Bidang Perdagangan & 8 \\
\hline $\begin{array}{l}\text { Kepala Dinas Perdagangan dan } \\
\text { Perindustrian Kota Surabaya }\end{array}$ & 10 \\
\hline
\end{tabular}

Sumber: Berdasarkan data yang diolah 
Tabel 2

Nilai power vote apabila pengguna berada di bagian lain

\begin{tabular}{|c|c|}
\hline Jabatan & Value Dalam Bagian Lain \\
\hline Pengadministrasian Umum 3 & 0,25 \\
\hline Pengadministrasian Umum 2 & 0,25 \\
\hline Jabatan & Value Dalam Bagian Lain \\
\hline Pengadministrasian Umum 1 & 0,5 \\
\hline Pengadministrasian Tertentu 3 & 0,5 \\
\hline Pengadministrasian Tertentu 2 & 0,5 \\
\hline Pengadministrasian Tertentu 1 & 0,75 \\
\hline Petugas Operasional 3 & 0,75 \\
\hline Petugas Operasional 2 & 0,75 \\
\hline Petugas Operasional 1 & 1 \\
\hline Penyelia Teknis 3 & 1 \\
\hline Penyelia Teknis 2 & 1 \\
\hline Penyelia Teknis 1 & 1,25 \\
\hline Perencana Teknis 3 & 1,25 \\
\hline Perencana Teknis 2 & 1,5 \\
\hline Perencana Teknis 1 & 1,5 \\
\hline Verifikator & 1,5 \\
\hline Analis 3 & 2 \\
\hline Analis 2 & 2,5 \\
\hline Analis 1 & 3 \\
\hline Sub Bagian Tata Usaha & 3,5 \\
\hline UPTD Pasar Turi & 4 \\
\hline Seksi Perdagangan Dalam Negeri & 3,5 \\
\hline Seksi Perdagangan Luar Negeri & 3,5 \\
\hline Kepala Bidang Perdagangan & 4 \\
\hline Jabatan & Value Dalam Bagian Lain \\
\hline $\begin{array}{l}\text { Seksi Logam, Mesin, Elektronika \& } \\
\text { Aneka }\end{array}$ & 3,5 \\
\hline $\begin{array}{l}\text { Seksi Industri Kimia, Agro \& Hasil } \\
\text { Hutan }\end{array}$ & 3,5 \\
\hline Kepala Bidang Industri & 4 \\
\hline Seksi Promosi & 3,5 \\
\hline Seksi Pendaftaran Perusahaan & 3,5 \\
\hline $\begin{array}{l}\text { Kepala Bidang Promosi \& Pendaftaran } \\
\text { Perusahaan }\end{array}$ & 4 \\
\hline Sub Bagian Umum \& Kepegawaian & 3,5 \\
\hline Sub Bagian Keuangan & 3,5 \\
\hline Kepala Bidang Perdagangan & 4 \\
\hline $\begin{array}{l}\text { Kepala Dinas Perdagangan } \\
\text { Perindustrian Kota Surabaya }\end{array}$ & 10 \\
\hline
\end{tabular}

Sumber: Berdasarkan data yang diolah 


\section{Analytical Hierarchy Process}

Analytical Hierarchy Process adalah hal utama yang ditekankan dalam aplikasi EInnovation ini. Metode Analytical Hierarchy Process dapat menilai secara objektif mengenai hal-hal yang sebelumnya sulit diukur seperti kualitas dari ide inovasi. Dalam E-Innovation, akan digunakan tiga level Analytical Hierarchy Process. Level satu adalah tujuan, yaitu menyaring tiga ide terbaik yang akan dibahas lebih lanjut oleh beberapa pimpinan teratas di rapat bulanan. Level dua berisi lima dimensi bisnis yang dapat diterapkan dalam E-Innovation di Dinas Perdagangan dan Perindustrian Kota Surabaya. Level tiga adalah enam ide inovasi terbaik yang akan diperoleh dari sistem web-based power vote dari E-Innovation.

Berdasarkan hasil wawancara, maka dimensi bisnis Fontana yang akan dipakai sebagai variabel level dua adalah konsumen, pengalaman konsumen, proses, rantai pasok, dan pasar. Bentuk dasar dari konstruksi Analytical Hierarchy Processnya adalah sebagai berikut:

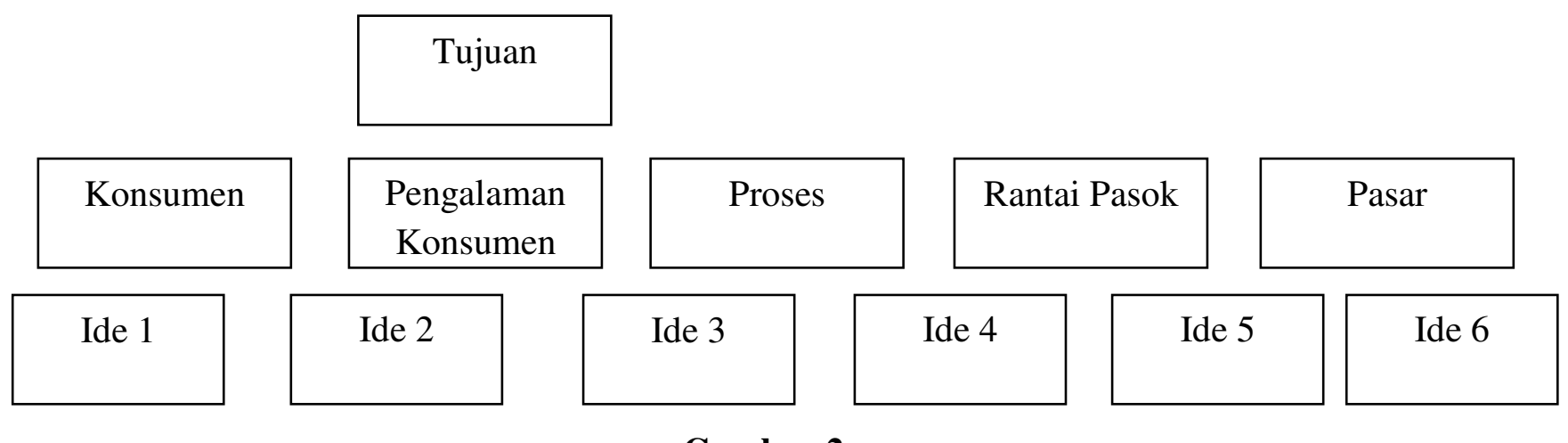

\section{Gambar 2}

Bentuk dasar konstruksi Analytical Hierarchy Process

Sumber: Avanti Fontana 2009

Langkah pertama, kita harus menentukan perbandingan skala fundamental dari masing-masing faktor yang berada di level kedua.

Setelah menentukan nilai kepentingan masing-masing, maka tiap kolom harus dijumlah untuk memudahkan perhitungan proses Analytical Hierarchy Process yang selanjutnya dengan tiga angka di belakang koma. Berikut adalah tabel yang menjelaskan perbandingan nilai kepentingan dari masing-masing faktor level dua dalam Analytical Hierarchy Process di E-Innovation.

Tabel 3

Perbandingan nilai kepentingan Analytical Hierarchy Process

\begin{tabular}{|l|l|l|l|l|l|}
\hline Goal & $\begin{array}{l}\text { Pengalaman } \\
\text { Konsumen }\end{array}$ & Konsumen & Proses & Pasar & $\begin{array}{l}\text { Rantai } \\
\text { Pasok }\end{array}$ \\
\hline $\begin{array}{l}\text { Pengalaman } \\
\text { Konsumen }\end{array}$ & 1 & 2 & 4 & 5 & 7 \\
\hline Konsumen & $1 / 2$ & 1 & 3 & 3 & 6 \\
\hline Proses & $1 / 4$ & $1 / 3$ & 1 & 2 & 5 \\
\hline Pasar & $1 / 5$ & $1 / 3$ & $1 / 2$ & 1 & 3 \\
\hline $\begin{array}{l}\text { Rantai } \\
\text { Pasok }\end{array}$ & $1 / 7$ & $1 / 6$ & $1 / 5$ & $1 / 3$ & 1 \\
\hline Jumlah & 2,093 & 3,826 & 8,700 & 11,330 & 22 \\
\hline
\end{tabular}

Sumber: Berdasarkan data diolah. 
Proses selanjutnya dalam Analytical Hierarchy Process adalah perhitungan bobot relatif yang dinormalkan pada masing-masing faktor diatas. Berikut adalah perhitungan untuk tiap faktor dengan lima angka di belakang koma.

Berikut adalah tabel yang menunjukkan hasil perhitungan bobot relatif dan eigenvector utama masing-masing faktor.

\section{Tabel 4}

Hasil perhitungan bobot relatif dan eigenvector utama masing-masing faktor.

\begin{tabular}{|l|l|l|l|l|l|l|}
\hline Goal & $\begin{array}{l}\text { Pengalaman } \\
\text { Konsumen }\end{array}$ & Konsumen & Proses & Pasar & $\begin{array}{l}\text { Rantai } \\
\text { Pasok }\end{array}$ & $\begin{array}{l}\text { Eigenvector } \\
\text { Utama }\end{array}$ \\
\hline $\begin{array}{l}\text { Pengalaman } \\
\text { Konsumen }\end{array}$ & 0,47778 & 0,52274 & 0,45977 & 0,44131 & 0,31818 & 0,44396 \\
\hline Konsumen & 0,23889 & 0,26137 & 0,34483 & 0,26478 & 0,27273 & 0,27652 \\
\hline Proses & 0,11945 & 0,08625 & 0,11494 & 0,17652 & 0,22727 & 0,14488 \\
\hline Pasar & 0,09556 & 0,08704 & 0,05747 & 0,08826 & 0,13636 & 0,09294 \\
\hline $\begin{array}{l}\text { Rantai } \\
\text { Pasok }\end{array}$ & 0,06832 & 0,04260 & 0,02299 & 0,02913 & 0,04546 & 0,04170 \\
\hline Jumlah & 1 & 1 & 1 & 1 & 1 & 1 \\
\hline
\end{tabular}

Sumber: Berdasarkan data yang diolah

Perhitungan level tiga tinggal memasukkan angka yang sudah dihitung diatas. Dengan Yi sebagai prosentase dari alternatif moda $\mathrm{i}$ dan $\mathrm{V}$ sebagai prosentase vote level kedua berdasarkan dimensi bisnis, maka rumus Analytical Hierarchy Process yang akan digunakan untuk E-Innovation adalah:

$\mathrm{Y} 1=($ Vpengalaman konsumen $(1) \times 0,44396)+($ Vkonsumen $(1) \times 0,27652)+(\operatorname{Vproses}(1)$ x 0,14488 $)+(\operatorname{Vpasar}(1)$ x 0,09294 $)+($ Vrantai pasok(1) x 0,04170 )

$\mathrm{Y} 2=($ Vpengalaman konsumen $(2) \times 0,44396)+($ Vkonsumen $(2) \times 0,27652)+(\operatorname{Vproses}(2)$ x 0,14488 $)+(\operatorname{Vpasar}(2) \times 0,09294)+($ Vrantai pasok(2) x 0,04170 $)$

$\mathrm{Y} 3=($ Vpengalaman konsumen $(3) \times 0,44396)+($ Vkonsumen $(3) \times 0,27652)+(\operatorname{Vproses}(3)$ x 0,14488) $+($ Vpasar(3) x 0,09294 $)+($ Vrantai pasok(3) x 0,04170 $)$

$\mathrm{Y} 4=($ Vpengalaman konsumen $(4) \times 0,44396)+($ Vkonsumen $(4) \times 0,27652)+($ Vproses $(4)$ x 0,14488 $)+($ Vpasar(4) x 0,09294 $)+($ Vrantai pasok(4) x 0,04170 )

Y5 $=($ Vpengalaman konsumen $(5) \times 0,44396)+($ Vkonsumen $(5) \times 0,27652)+(\operatorname{Vproses}(5)$ x 0,14488 $)+(\operatorname{Vpasar}(5) \times 0,09294)+($ Vrantai $\operatorname{pasok}(5) \times 0,04170)$

Y6 $=($ Vpengalaman konsumen $(6) \times 0,44396)+($ Vkonsumen $(6) \times 0,27652)+(\operatorname{Vproses}(6)$ x 0,14488 $)+(\operatorname{Vpasar}(6) \times 0,09294)+($ Vrantai pasok(6) x 0,04170 $)$ 
Berikut adalah contoh perhitungan nilai Analytical Hierarchy Process dalam PHP:



\section{Kesimpulan}

Berdasarkan perancangan dan prototype yang telah dibuat, maka dapat ditarik kesimpulan bahwa:

1. Aplikasi E-Innovation dapat memberikan satu platform bagi Dinas Perdagangan dan Perindustrian Kota Surabaya untuk menilai sebuah ide inovasi secara lebih objektif menggunakan power vote dan Analytical Hierarchy Process.

2. Aplikasi E-Innovation telah berhasil dibuat prototypenya dengan fitur-fitur sebagai berikut:

a. Fitur memberikan ide inovasi telah berhasil dibuat untuk memungkinkan semua karyawan di Dinas Perdagangan dan Perindustrian Kota Surabaya dapat memberikan ide inovasi mereka untuk kemudian dinilai menggunakan E-Innovation.

b. Fitur memberikan komentar dalam ide inovasi telah berhasil dibuat untuk memungkinkan semua karyawan di Dinas Perdagangan dan Perindustrian Kota Surabaya bisa memberikan komentar terhadap ide inovasi dan berdiskusi tentang hal tersebut.

c. Fitur memberikan vote dalam ide inovasi telah berhasil dibuat untuk memungkinkan semua karyawan di Dinas Perdagangan dan Perindustrian Kota Surabaya bisa memberikan vote terhadap ide inovasi yang mereka sukai.

d. Fitur power vote dalam ide inovasi telah berhasil dibuat untuk memungkinkan semua karyawan di Dinas Perdagangan dan Perindustrian mempunyai nilai votenya sendiri-sendiri tergantung dengan jabatan dan department mereka.

e. Fitur Analytical Hierarchy Process telah berhasil dibuat untuk memungkinkan semua ide inovasi yang sudah lolos pada tahap vote akan dinilai menggunakan metode Analytical Hierarchy Process sesuai dengan nilai faktor yang dihitung secara akurat berdasarkan hasil wawancara. 
3. Aplikasi E-Innovation tidak dapat memasukkan pengalaman seseorang dalam bagian lain.

4. Aplikasi E-Innovation tidak dapat melakukan perbaikan secara berjenjang pada ide awal.

\section{Saran}

Dari perancangan dan prototype yang telah dilakukan, maka didapatkan beberapa saran untuk penelitian-penelitian kedepan antara lain:

1. Penggunaan faktor-faktor lain untuk Analytical Hierarchy Process selain dimensi bisnis Fontana.

2. Menyediakan waktu yang lebih banyak untuk melakukan testing dalam aplikasi.

3. Membuat desain yang jauh lebih menarik.

4. Pembuatan aplikasi E-Innovation ke dalam platform lain seperti iPhone, iPad, Windows Mobile, dan Android.

\section{Daftar Pustaka}

Barton Rabe, Cynthia. 2006. The Innovation Killer. New York: Amacom.

Beighley, Lynn \& Michael Morrison,.2009. Head First PHP and MySQL.USA: O־Reilly.

Duarte, Deborah L \& Nancy Tennant Snyder. 2008. Unleashing Innovation, how whirlpool transformed an industry. San Francisco: Jossey-Bass.

Fontana, Avanti. 2009. Innovate We Can! How to Create Value Through Innovation in Your Organization and Society. Jakarta: Cipta Inovasi Sejahtera.

Heller, Robert, \& Herbayu Noerlambang. 2008. Bill Gates: Jenius Revolusi Software dan Master Abad Informasi. Jakarta: Esensi.

Kroenke, David M. 2004.Database Processing Fundamental, Design and Implementation. USA: Pearson.

Mulyana, Deddy, Solatun. 2007. Metode Penelitian Komunikasi: Contoh-Contoh Penelitian Kualitatif dengan Pendekatan Praktis. Bandung: PT.Remaja Rosdakarya.

Munadi, Ernawati, \& Wayan R. Susila. 2007. Penggunaan Analytical Hierarchy Process Untuk Penyusunan Prioritas Penelitian. Jurnal Informatika Pertanian Volume 16 No 2.

Peraturan Walikota Surabaya Nomor 91 Tahun 2008 Tentang Rincian Tugas dan Fungsi Dinas Kota Surabaya.

Powell, Gavin.2006. Beginning Database Design. USA: Wiley Publishing.

Revisi Usulan Jabatan Staf Dinas Perdagangan dan Perindustrian Kota Surabaya Tahun 2012.

Richardson, Adam.2010. Why a Company Toughest Problems are its Greatest Advantage. San Francisco: Jossey-Bass. 
Sevilla, Consuelo G [et al.], Alimuddin Tuwu. 1993. Pengantar Metode Penelitian. Jakarta: Penerbit Universitas Indonesia.

Siswanto, Hendro, \& Sebastianus Ari Yudhanto. 1999. Penggunaan Metode Analytic Hierarchy Process Dalam Menganalisa Faktor-Faktor yang Mempengaruhi Pemilihan Moda ke Kampus. Jurnal Dimensi Teknik Sipil Volume 1, No. 1.

Terwiesch, Christian, \& Karl T.Ulrich. 2009. Innovation Tournaments: Creating and Selecting Exceptional Opportunities. Boston: Harvard Business Press. 